\title{
Plasma cell-free DNA integrity plus circulating tumor cells: a potential biomarker of no distant metastasis breast cancer
}

W. WANG, M. LIANG, G. MA, L. LI, W. ZHOU, T. XIA, H. XIE, S. WANG*

Department of Breast Surgery, The First Affiliated Hospital of Nanjing Medical University, China

${ }^{*}$ Correspondence: ws0801@hotmail.com

Received October 11, 2016 / Accepted January 19, 2017

Cell-free DNA integrity (cfDI) is a promising diagnostic and prognostic biomarker in breast cancer. However, no specific study has evaluated the diagnostic ability of cfDI in patients with no distant metastasis breast cancer (no-MBC) and benign breast tumor (BBT) to date. We assessed the plasma cfDI of 84 patients with no-MBC and 30 patients with BBT using quantitative PCR and compared it with circulating tumor cells (CTCs) and carbohydrate antigen 153 (CA153). The no-MBC group had significantly lower mean cfDI $(0.58)$ than the BBT group $(0.74, \mathrm{p}=0.004)$. Subgroup analysis showed that decreased cfDI seem to be associated with risk factors such as age $<45$ years (mean $\mathrm{cfDI}=0.52$ ), triple-negative breast cancer (mean cfDI $=0.56), \mathrm{Ki} 67>14 \%($ mean $\mathrm{cfDI}=0.57)$, tumor size $>2 \mathrm{~cm}($ mean $\mathrm{cfDI}=0.58)$, and positive lymph node status (mean cfDI $=0.56$ ), but had no statistical significance. McNemar's test suggested that cfDI had stronger diagnostic power than CTCs, cfDNA concentration, or CA153 ( $\mathrm{p}<0.001)$. Spearman's rho showed that the correlation coefficient between cfDI and CTCs was $0.278(\mathrm{p}=0.04)$ in the no-MBC group. Receiver operating characteristic curve analysis also suggested that cfDI was superior to CTCs or CA153. Combined with CTCs, cfDI reduced the false positive rate from $50 \%$ to $10.71 \%$ and increased the area under the curve value from 0.66 to 0.68 . Our results suggest that cfDI is a potential diagnostic biomarker of no$\mathrm{MBC}$. Using cfDI and CTCs as a combined diagnostic tool for no-MBC could improve diagnostic sensitivity and specificity but more samples will be needed.

Key words: cell-free DNA, cell-free DNA integrity, circulating tumor cell, no distant metastasis breast cancer

In the clinic, breast cancer (BC) is diagnosed by pathological examination. However, as information acquired from a single biopsy provides a spatially and temporally limited snapshot of a tumor, serial sampling of the tumor to monitor disease status or treatment response represents a prerequisite for personalized therapy [1-3]. Blood-based biomarkers have advantages over tissue biopsy because they can be accessed via minimally invasive procedures, and multiple samples can be obtained over a specific period [4]. Therefore, circulating biomarkers, which can provide more information on the tumor status, may be an excellent alternative. Traditional circulating biomarkers, such as carcinoembryonic antigen (CEA) and carbohydrate antigen 153 (CA153), have low sensitivity and specificity [5]. Recently, cell-free DNA (cfDNA) in blood has attracted increasing attention, and different cancerassociated cfDNA molecular characteristics, including copy number aberrations, methylation changes, single-nucleotide mutations, cancer-derived viral sequences, and chromosomal rearrangements, have been extensively studied [6]. Furthermore, cfDNA integrity (cfDI), which measures the extent of cfDNA fragmentation, has also been exploited as a diagnostic and prognostic biomarker in cancer [7]. As a biomarker, cfDI has practical advantages, including high sensitivity, noninvasiveness, and repeatability. For example, serum can be obtained easily, and the quick and well-established quantitative PCR (qPCR) method, requiring small amounts of blood, is a relatively cost-efficient technology [8]; in the circulation, DNA has a shorter half-life, ranging from $15 \mathrm{~min}$ to several hours, which can represent the real-time status of a tumor [9, 10]. Some studies have proven that cfDNA is detected sooner and more frequently than circulating tumor cells (CTCs) $[11,12]$. However, previous studies have formed inconsistent conclusions on cfDI in patients with cancer. Using qPCR with different amplicon sizes, some studies have demonstrated a higher proportion of longer DNA and increased cfDI in patients with cancer as compared with subjects without a ma- 
lignant condition [13-15]. On the other hand, contradictory evidence has shown that the shorter DNA molecules preferentially carry tumor-associated copy number aberrations and that cfDNA from tumor tissues might be shorter than that of nonmalignant cells $[16,17]$. Reduced cfDI and increased cfDNA concentration could serve as diagnostic markers of primary BC and metastatic BC [18]. Although studies have assessed the clinical significance of cfDI in patients with BC and in healthy volunteers, few studies have focused on patients with benign BC (BBT) and no distant metastasis BC (no$\mathrm{MBC}$ ). Moreover, some studies have compared the diagnostic sensitivity of cfDI with CTCs but reached inconsistent conclusions [19-22]. In these studies, CTCs and cfDNA were often detected using different research platforms with differing detection sensitivity. Therefore, more studies using the same detection platform are needed for different breast diseases.

The absolute plasma DNA level is influenced by DNase I [14]. Some reports have suggested that DNase I activity in the circulation of patients with malignancies, such as prostate tumor, is decreased significantly compared with that of healthy controls $[23,24]$. However, DNase I levels and whether cfDI is influenced by DNase I in breast tumor have not been studied to date.

In this study, we discuss the clinical significance of $\mathrm{cfDI}$ between patients with BBT and patients with no-MBC and investigated the diagnostic sensitivity of cfDI and CTCs using the same platform. Furthermore, we also tested plasma DNase I levels to explore whether they are related with cfDI in breast tumor.

\section{Materials and methods}

Subjects and plasma sample preparation. Between 2013 and 2015, 114 patients were recruited at the Department of Breast Surgery of Jiangsu Province Hospital. The subjects included patients with no-MBC $(n=84)$ and patients with BBT $(n=30)$. The no-MBC cohort consisted of patients with early $B C(n=57)$ and locally advanced BC $(n=27)$. All subjects were females. Blood was collected from the patients at the time of diagnosis before they underwent any therapy. Patients with BBT comprised individuals with no clinically diagnosed malignancies, autoimmune diseases, or infection. This study was approved by the ethical and scientific committee of our institution.

To reduce blood contamination by epithelial cells from the skin, the first $2 \mathrm{ml}$ blood was discarded and the collection tube was disconnected before the needle was withdrawn at the end of the procedure. Peripheral blood (10 $\mathrm{ml}$ in EDTA) was collected and then shipped at room temperature within $2 \mathrm{~h}$ to the molecular diagnostic laboratory for immediate processing by Ficoll density gradient centrifugation (STEMCELL Technologies, Canada) according to the protocol. The supernatant plasma was centrifuged again at 2,000 $\times g$ for 10 min at $4^{\circ} \mathrm{C}$ to minimize any contamination from blood cells or cell debris. Mononuclear cells were collected and dissolved in $1 \mathrm{ml}$ RNAiso Plus (TaKaRa, Japan). All samples were stored at $-80^{\circ} \mathrm{C}$ until further use.
DNA extraction from plasma. DNA was extracted from $200 \mu \mathrm{l}$ plasma using a QIAamp DNA Blood Mini Kit (Qiagen, Germany) according to the kit protocol, and the final eluate was collected and stored at $-20^{\circ} \mathrm{C}$. Samples from different groups were always extracted together to avoid batch effects.

RNA extraction and complementary DNA (cDNA) synthesis. Total RNA was extracted according to the RNAiso Plus protocol. RNA quantification and purity assessment were performed by optical density measurement at $260 \mathrm{~nm}$ and $280 \mathrm{~nm}$. RNA reverse transcription was carried out using the PrimeScript RT Master Mix system (TaKaRa). The cDNA was synthesized from $1 \mu \mathrm{g}$ total RNA isolated from the peripheral blood mononuclear cells of the patients in a total volume of $20 \mu \mathrm{l}$ according to the manufacturer's instructions.

Estimation of cfDI and cfDNA concentration with Alu repetitive elements. The $\mathrm{cfDI}$ and $\mathrm{cfDNA}$ concentration were derived by analyzing Alu repetitive elements. For this, a short (111 bp) and long (260 bp) fragment were measured in triplicate by qPCR using an Absolute SYBR Green assay with the Step One Plus Real-Time PCR System (Applied Biosystems, USA). Primers were designed according to a previous report (Supplementary Table 1) [18]. PCR was performed with FastStart Universal SYBR Green Master (Rox, Germany) according to the manufacturer's instructions in a final volume of $20 \mu \mathrm{l}$ containing $10 \mu \mathrm{l} 2 \times$ SYBR Green, $0.2 \mu \mathrm{l} 10 \mu \mathrm{M}$ PCR forward primer, $0.2 \mu \mathrm{l} 10 \mu \mathrm{M}$ PCR reverse primer, $1 \mu \mathrm{l} \mathrm{DNA}$ template, and $8.6 \mu$ distilled water $\left(\mathrm{dH}_{2} \mathrm{O}\right)$. The thermal cycling conditions were $10 \mathrm{~min}$ at $95^{\circ} \mathrm{C}$ and 40 cycles of denaturation at $95^{\circ} \mathrm{C}$ for $15 \mathrm{~s}$, annealing at $60^{\circ} \mathrm{C}$ for $60 \mathrm{~s}$, and extension at $72^{\circ} \mathrm{C}$ for $15 \mathrm{~s}$.

A known-concentration DNA standard was divided into five copies and diluted to $1 \mathrm{ng} / \mathrm{ml}, 10 \mathrm{ng} / \mathrm{ml}, 100 \mathrm{ng} / \mathrm{ml}$, $1000 \mathrm{ng} / \mathrm{ml}$, and $10000 \mathrm{ng} / \mathrm{ml}$. DNA concentration-Ct value standard curves were constructed. The respective absolute concentration of the long and short fragment was calculated and the cfDI was subsequently calculated as the ratio of long fragment concentration to short fragment concentration. The total cfDNA concentration of a sample was derived from the short fragment concentration.

CTC detection. CTCs were detected using a previously reported qPCR method [25]. The marker genes included cytokeratin 19 (CK19), human mammaglobin (hMAM), and small breast epithelial mucin (SBEM). The housekeeping gene was beta-cytoplasmic actin 2 ( $\beta$-actin, ACTB). All PCR were performed using the fluorescent SYBR Green I methodology. PCR was performed with FastStart Universal SYBR Green Master (Rox) in a final volume of $20 \mu \mathrm{l}$ containing $10 \mu \mathrm{l} 2 \times$ SYBR Green, $0.4 \mu \mathrm{l} 10 \mu \mathrm{M}$ PCR forward primer, $0.4 \mu \mathrm{l} 10 \mu \mathrm{M}$ PCR reverse primer, $2 \mu \mathrm{l}$ cDNA template, and $7.2 \mu \mathrm{d} \mathrm{d}_{2} \mathrm{O}$. The thermal cycling conditions were $10 \mathrm{~min}$ at $95^{\circ} \mathrm{C}$ and 40 cycles of denaturation at $95^{\circ} \mathrm{C}$ for $15 \mathrm{~s}$, annealing at $60^{\circ} \mathrm{C}$ for $60 \mathrm{~s}$, and extension at $72^{\circ} \mathrm{C}$ for $15 \mathrm{~s}$. The $C K 19, \mathrm{~h} M A M$, and $S B E M$ mRNA quantities were analyzed in triplicate, and normalized against the ACTIN control gene. Results were expressed as relative gene expression using the comparative threshold cycle 
$\left(2^{-\Delta \Delta C t}\right)$ method. A relative gene expression value of 1 of the mRNA markers was derived from the mRNA expression in the peripheral blood from a healthy female volunteer. Gene positivity was defined as expression above the cut-off threshold, which was set for each gene marker at three sd from the mean expression in BBT samples. CTC positivity was defined as positivity for at least one marker.

Detection of CA153 and plasma DNase I levels. CA153 was detected in the central laboratory of Jiangsu Province Hospital. DNase I levels were tested with an enzyme-linked immunosorbent assay kit (Cloud-Clone, USA) according to the manufacturer's protocol.

Data analysis. Statistical analysis was performed using SPSS 20 (IBM, USA). The normal distribution of the parameters was assessed and most followed normal distribution, except DNase I, which was calculated using the nonparametric test. Comparisons between two groups were made using Student's $t$-test; comparisons between three groups were made using one-way analysis of variance (ANOVA), and homogeneity of variance was evaluated using Bartlett's test. Paired data in $2 \times 2$ contingency tables were tested using McNemar's test. Receiver operating characteristic (ROC) analysis was performed to assess the discriminatory power of cfDI, cfDNA concentration, CTCs, and CA153 between two groups, and the corresponding area under the curve (AUC) was calculated. For binary variables such as CTCs, binary logistic analysis first was performed to produce predicted probabilities. Correlation coefficients were calculated with Pearson analysis for continuous variables and with Spearman's rho for binary variables.

Table 1. Patient characteristics

\begin{tabular}{|c|c|c|c|}
\hline & Benign breast tumor & \multicolumn{2}{|c|}{ Breast cancer } \\
\hline \multicolumn{4}{|l|}{ Age (years) } \\
\hline Median (range) & $42.5(20-67)$ & \multicolumn{2}{|c|}{$49(28-82)$} \\
\hline \multicolumn{4}{|l|}{ Menopausal status (n, \%) } \\
\hline Premenopausal & 21.9 & 49 & 43.0 \\
\hline Postmenopausal & 4.4 & 35 & 30.7 \\
\hline \multicolumn{4}{|l|}{ Histological type (n, \%) } \\
\hline Fibroadenoma & 7.0 & & \\
\hline Intraductal papilloma & 10.5 & & \\
\hline Nodal mastopathy & 8.8 & & \\
\hline DCIS & & 2 & 1.8 \\
\hline IDC & & 70 & 61.4 \\
\hline Other & & 12 & 10.5 \\
\hline \multicolumn{4}{|l|}{ Molecular type (n, \%) } \\
\hline Luminal A & & 7 & 6.1 \\
\hline Luminal B & & 48 & 42.2 \\
\hline HER2 & & 21 & 18.4 \\
\hline TNBC & & 8 & 7.0 \\
\hline \multicolumn{4}{|l|}{$\operatorname{Ki67}^{\star}(\mathbf{n}, \%)$} \\
\hline$\leq 14 \%$ & & 13 & 11.4 \\
\hline$>14 \%$ & & 67 & 58.8 \\
\hline
\end{tabular}

${ }^{*}$ Part of the information was lost. TNBC $=$ triple-negative breast cancer.

\section{Results}

Study inclusion and patient characteristics. Table 1 lists the clinical and histological data of the patients, including age, menopausal status, pathological type, molecular type, and Ki67 index.

Standard curve setting. We constructed standard curves (Supplementary Figure 1). The $\mathrm{R}^{2}$ of each curve was $>0.99$. The PCR efficiencies of all primer pairs were $>70 \%$ [ALU (111 bp): 88.92\%, ALU (260 bp): 71.55\%]. Primer specificity was confirmed by melt curve analysis, and no multiple peaks were found. The concentration-Ct value formula was: $\mathrm{Y}_{(111 \mathrm{bp})}$ $=-3.62 \mathrm{X}+25.41, \mathrm{Y}_{(260 \mathrm{bp})}=-4.266 \mathrm{X}+29.993$

Comparison of cfDI between patients with no-MBC and patients with BBT. The mean cfDI (0.58) of the no-MBC group was significantly lower than that of the BBT group $(0.74, \mathrm{p}=0.004)$. The mean ALU concentration of the noMBC group (135.74 ng/ml) was greater than that of the BBT group (121.62 ng/ml), but had no statistical significance ( $\mathrm{p}$ $=0.89$ ). Subgroup analysis showed no significant difference. But we found that decreased cfDI appeared to be associated with high risk factors of prognosis, such as age $<45$ years (mean cfDI $=0.52$ ), triple-negative BC [TNBC (mean cfDI $=0.56)$, Ki67 > 14\% (mean cfDI $=0.57)$, tumor size $>2 \mathrm{~cm}$ (mean $\mathrm{cfDI}=0.58$ ), and positive lymph node status (mean cfDI $=0.56$, Table 2).

Table 2. Differences in cfDI values between groups

\begin{tabular}{|c|c|c|c|}
\hline Group & Number (\%) & cfDI & $\mathbf{p}$ \\
\hline Benign breast tumor & $30(26.3)$ & 0.74 & 0.004 \\
\hline Breast cancer & $84(73.7)$ & 0.58 & \\
\hline Age (years) & & & 0.090 \\
\hline$<45$ & $28(24.6)$ & 0.52 & \\
\hline $45-55$ & $31(27.2)$ & 0.66 & \\
\hline$>55$ & $25(21.9)$ & 0.56 & \\
\hline Menopausal status* & & & 0.690 \\
\hline Pre-menopausal & $48(42.1)$ & 0.59 & \\
\hline Post-menopausal & $34(29.8)$ & 0.57 & \\
\hline Molecular subtype & & & 0.940 \\
\hline Luminal & $55(48.3)$ & 0.59 & \\
\hline HER2 & $21(18.4)$ & 0.59 & \\
\hline TNBC & $8(7.0)$ & 0.56 & \\
\hline $\mathrm{Ki}^{*}$ & & & 0.090 \\
\hline$\leq 14$ & $13(11.4)$ & 0.69 & \\
\hline$>14$ & $67(58.8)$ & 0.57 & \\
\hline Tumor diameter $(\mathrm{cm})^{\star}$ & & & 0.390 \\
\hline$\leq 2$ & $35(30.7)$ & 0.65 & \\
\hline$>2 \mathrm{~cm}$ & $21(18.4)$ & 0.58 & \\
\hline Lymph node status* & & & 0.180 \\
\hline No & $37(32.5)$ & 0.66 & \\
\hline N1-N3 & $17(14.9)$ & 0.56 & \\
\hline
\end{tabular}


Assessment of diagnostic capability of cfDI, cfDNA concentration, CTCs, and CA153. In addition to testing the plasma DNA concentration and cfDI in all cases, we also studied the CTCs in 51 no-MBC and 28 BBT cases. In the 51 no-MBC cases, the positive rate of CTCs was $43.14 \%$ (22/51, Table 3), which was lower than the cfDI $[72.55 \%$ $(37 / 51)]$ when the cfDI cut-off threshold was set to 0.74 (meeting the best diagnostic sensitivity and specificity). However, the false positive rate of cfDI $(50 \%, 14 / 28)$ was higher than that of the CTCs $(21.43 \%, 6 / 28)$. The cfDI and CTCs both were positive in $37.25 \%$ (19/51) of no-MBC cases and in $10.71 \%(3 / 28)$ of BBT cases. McNemar's test suggested that $\mathrm{cfDI}$ had stronger diagnostic power than CTCs, cfDNA concentration, and CA153 ( $p<0.001$, Table 4). Spearman's rho showed that the correlation coefficient

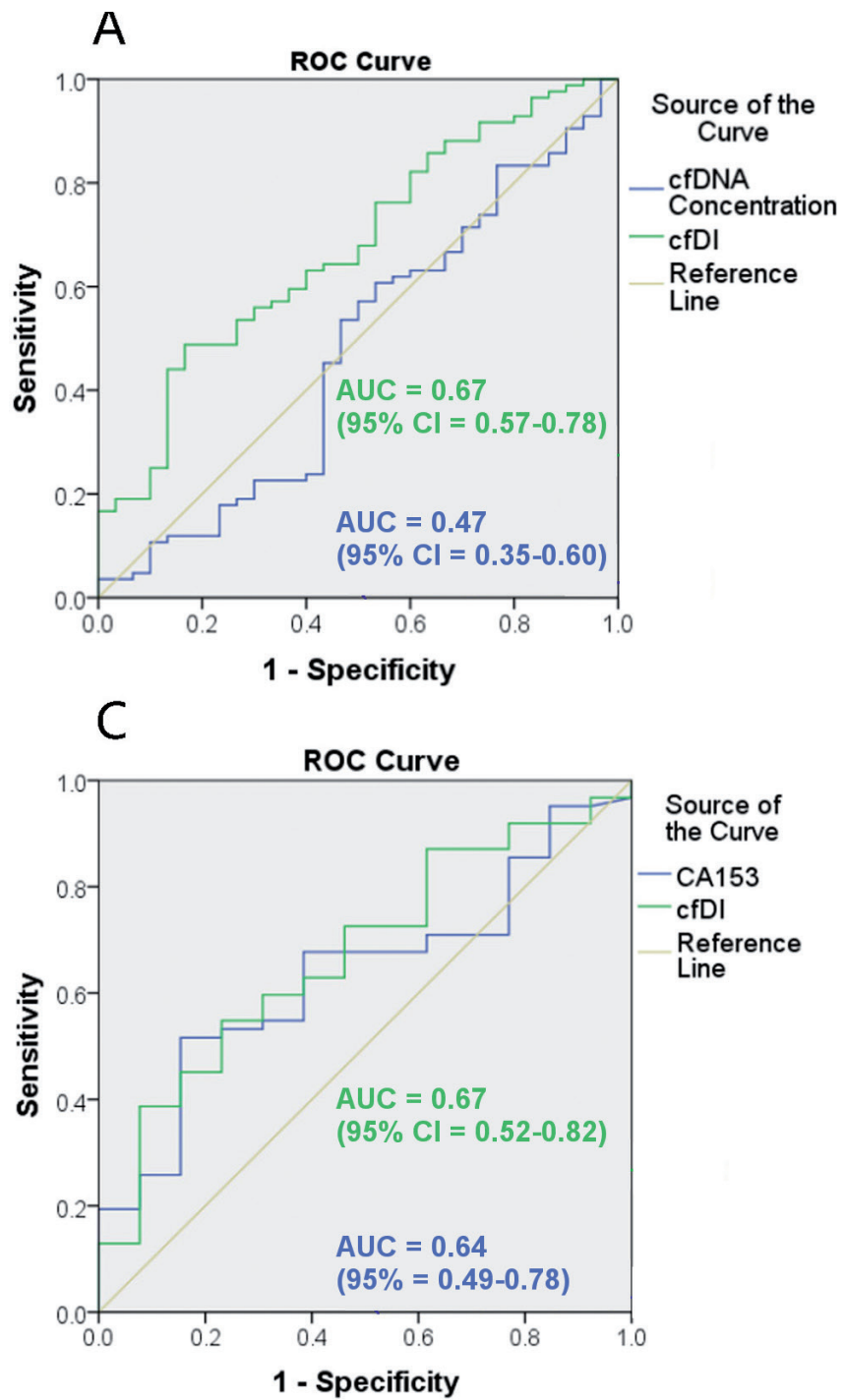

between cfDI and CTCs was $0.203(\mathrm{p}=0.062)$ in all cases, but was $0.278(\mathrm{p}=0.04)$ in the no-MBC cases.

ROC curve analysis showed that cfDI had a larger AUC than $\mathrm{cfDNA}$ concentration $(\mathrm{cfDI}=0.67$, $\mathrm{cfDNA}$ concentration $=0.47)$, CTCs $(\mathrm{cfDI}=0.66, \mathrm{CTCs}=0.61)$, or CA153 (cfDI $=$ 0.67 , CA153 $=0.64$ ). When the conjoint analysis of $\mathrm{cfDI}$ and CTCs was performed, the specificity and sensitivity could be improved (AUC $=0.680$, Figure 1 ).

Detection of plasma DNase I levels. We found no remarkable difference between plasma DNase I levels in the patients with no-MBC and the patients with BBT ( $\mathrm{p}=0.217$, Figure 2). Correlation analysis showed remarkable positive correlation between cfDI and DNase I levels $(r=0.416, p<0.001)$, but not between DNase I levels and cfDNA concentration ( $\mathrm{r}$ $=0.158, p=0.143$, Figure 3 ).

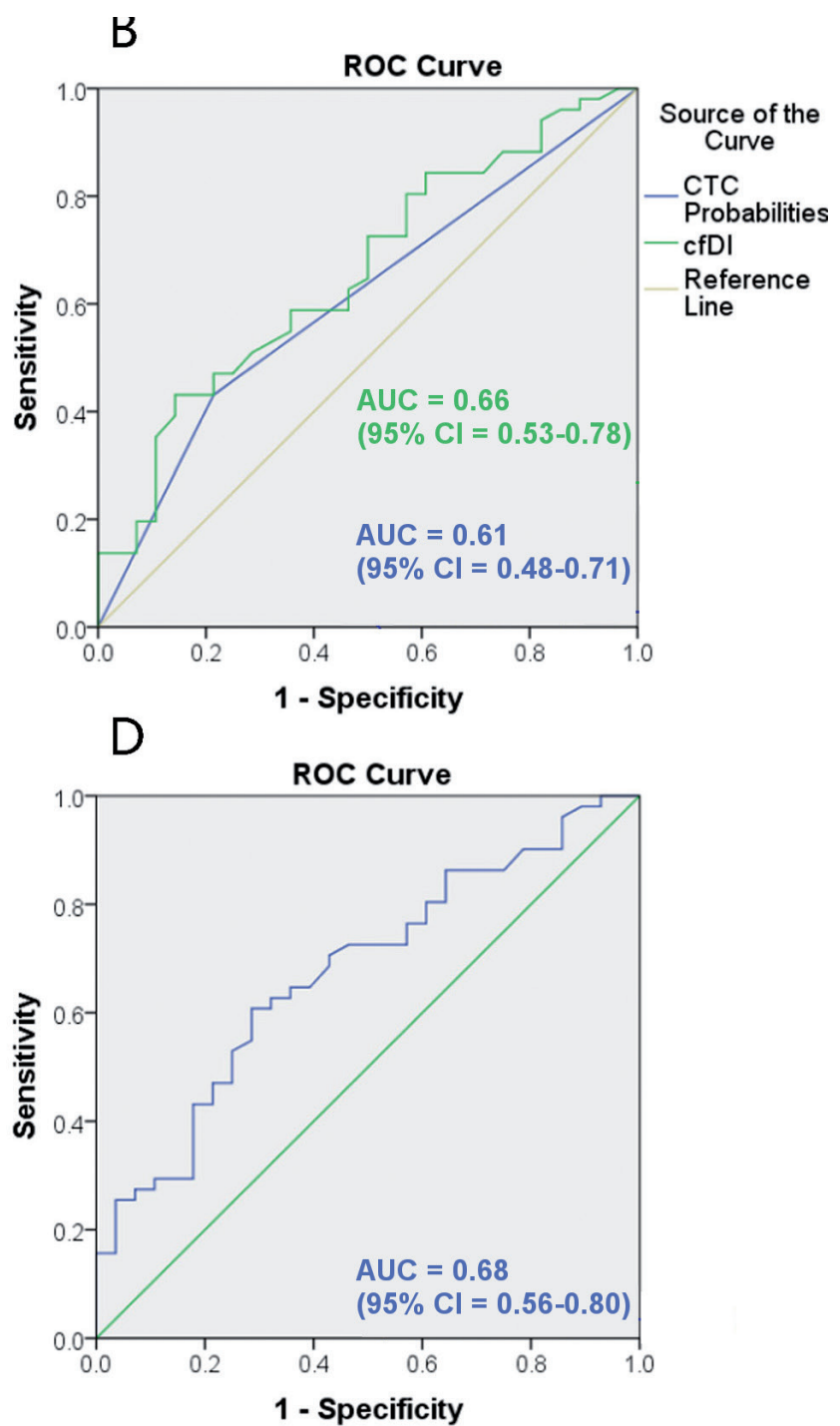

Figure 1. ROC curves of cfDI, cfDNA concentration, CTCs, and CA153. A. Comparison of AUC between cfDI and cfDNA concentration; B. cfDI and CTCs; C. cfDI and CA153; D. Conjoint analysis of cfDI and CTCs. 


\section{Discussion}

In the present study, the mean cfDI value of the no-MBC group was significantly lower than that of the BBT group. Subgroup analysis showed that decreased cfDI appeared to be associated with high risk factors of prognosis, such as age $<$ 45 years, TNBC, $\mathrm{Ki} 67>14 \%$, tumor size $>2 \mathrm{~cm}$, and positive lymph node status but had no statistical significance. Moreover, cfDI had stronger diagnostic power than CTCs, cfDNA concentration, and CA153. Correlation analysis showed that cfDI correlated positively with CTCs in the no-MBC group as well as with DNase I level in all patients. ROC analysis suggested that the cfDI AUC was greater than that of cfDNA concentration, CTCs, and CA153. However, cfDI had a higher false positive rate $(50 \%)$. If cfDI and CTCs were considered together, the AUC value reached 0.68 , and the false positive rate dropped to $10.71 \%$. We demonstrate that cfDI plus CTCs could be a promising diagnostic biomarker in the differential diagnosis of no-MBC and BBT. However, the sample size in this study was small and the survival data were not available because of the short study duration. Therefore, more studies should be done to confirm the clinical significance of cfDI.

Our findings are the opposite of that of previous studies that reported increased cfDI among patients with cancer. This contradiction could be partly due to the following reasons. First, the source of cfDNA is unclear. Some studies believed that the increased cfDI is associated with cfDNA derived from apoptotic and necrotic cells in patients with cancer, while it is derived only from apoptotic cells in healthy individuals [26, 27]. Apoptotic cells release DNA fragments that are usually 185-200-bp in length, while DNA fragments from necrotic cells vary in size and can even be several kilobase pairs [28].

Table 3. Detection of CK19, hMAM and SBEM

\begin{tabular}{|c|c|c|}
\hline & Benign tumor & Breast cancer \\
\hline \multicolumn{3}{|l|}{ RGE of CK19 } \\
\hline $\mathrm{N}$ & 28 & 51 \\
\hline No. of patient $>$ cut-off ${ }^{a}$ & 2 & 8 \\
\hline Positive rate (\%) & 7.14 & 15.69 \\
\hline \multicolumn{3}{|l|}{ RGE of hMAM } \\
\hline $\mathrm{N}$ & 28 & 51 \\
\hline No. of patient $>$ cut-off ${ }^{a}$ & 2 & 13 \\
\hline Positive rate (\%) & 7.14 & 25.49 \\
\hline \multicolumn{3}{|l|}{ RGE of SBEM } \\
\hline $\mathrm{N}$ & 28 & 51 \\
\hline No. of patient $>$ cut-off ${ }^{a}$ & 2 & 3 \\
\hline Positive rate (\%) & 7.14 & 5.88 \\
\hline Two or three marker positive rate (\%) & 0 & $3.92(2 / 51)$ \\
\hline Total positive rate (\%) & 21.42 & 43.14 \\
\hline \multicolumn{3}{|c|}{$\begin{array}{l}\beta \text {-actin = beta-cytoplasmic actin } 2 \text {; CK19 = cytokeratin } 19 ; \text { hMAM }=\text { humar } \\
\text { mammaglobin; SBEM = small breast epithelial mucin; RGE = relative gen } \\
\text { expression. } \\
\text { aThe cut-off was set for each gene marker at three sd from the mean expres } \\
\text { sion in BBT samples. }\end{array}$} \\
\hline
\end{tabular}

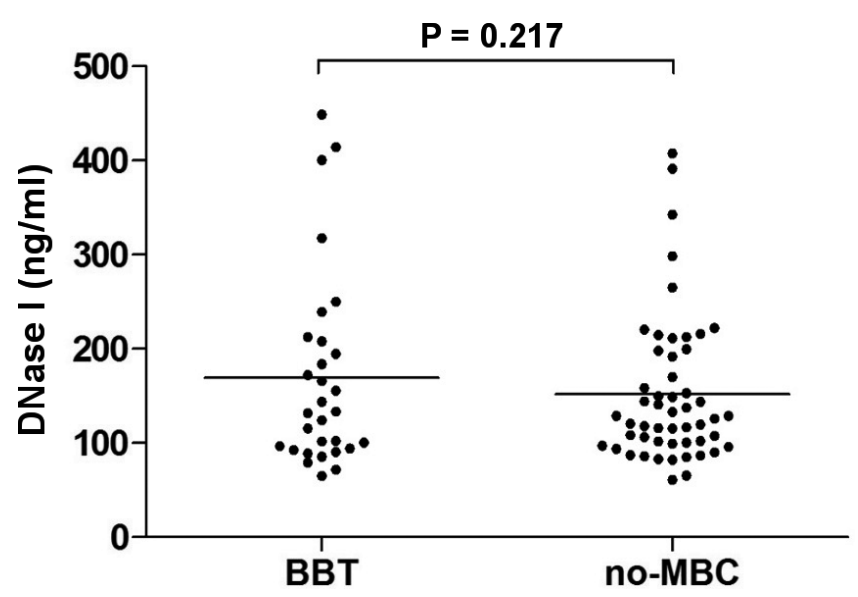

Figure 2. Comparison of DNase I level in the plasma of no-MBC cases and $\mathrm{BBT}$ controls. $\mathrm{BBT}=$ benign breast tumor; no-MBC $=$ no distant metastatic BC.

Different sources have been proposed as the cause of the increased cfDI observed in patients with cancer [29]. However, this inference has not been confirmed by experimental proof showing that the majority of cfDNA from patients with cancer is indeed from necrotic and apoptotic cells and that cfDNA from healthy subjects is from apoptotic cells.

Table 4. Comparisons between cfDI with CTCs, cfDNA concentration, or CA153

\begin{tabular}{|c|c|c|c|}
\hline & \multicolumn{3}{|c|}{ cfDI (n) } \\
\hline & $<0.74$ & $\geq 0.74$ & Total \\
\hline \multicolumn{4}{|l|}{ CTCs (n) } \\
\hline Positive (any marker above the cut-off threshold) & 19 & 3 & 22 \\
\hline Negative (all markers below the cut-off threshold) & 18 & 11 & 29 \\
\hline Total & 37 & 14 & 51 \\
\hline \multicolumn{4}{|l|}{ cfDI positive rate, $72.55 \%(37 / 51)$} \\
\hline \multicolumn{4}{|l|}{ CTC positive rate, $43.14 \%(22 / 51)$} \\
\hline \multicolumn{4}{|l|}{$\mathrm{p}<0.001$} \\
\hline \multicolumn{4}{|l|}{ cfDNA concentration (n) } \\
\hline Abnormal (above the cut-off threshold) & 30 & 10 & 40 \\
\hline Normal (below the cut-off threshold) & 32 & 12 & 44 \\
\hline Total & 62 & 22 & 84 \\
\hline \multicolumn{4}{|l|}{ cfDI positive rate, $73.81 \%(62 / 84)$} \\
\hline \multicolumn{4}{|l|}{ cfDNA positive rate, $47.62 \%(40 / 84)$} \\
\hline \multicolumn{4}{|l|}{$\mathrm{p}<0.001$} \\
\hline \multicolumn{4}{|l|}{ CA153 (n) } \\
\hline Abnormal $(\geq 25 \mathrm{U} / \mathrm{ml})$ & 3 & 1 & 4 \\
\hline Normal $(<25 \mathrm{U} / \mathrm{ml})$ & 41 & 17 & 58 \\
\hline Total & 44 & 18 & 62 \\
\hline \multicolumn{4}{|l|}{ cfDI positive rate, $70.97 \%(44 / 62)$} \\
\hline \multicolumn{4}{|l|}{ CA153 positive rate, $6.45 \%(4 / 62)$} \\
\hline $\mathrm{p}<0.001$ & & & \\
\hline
\end{tabular}




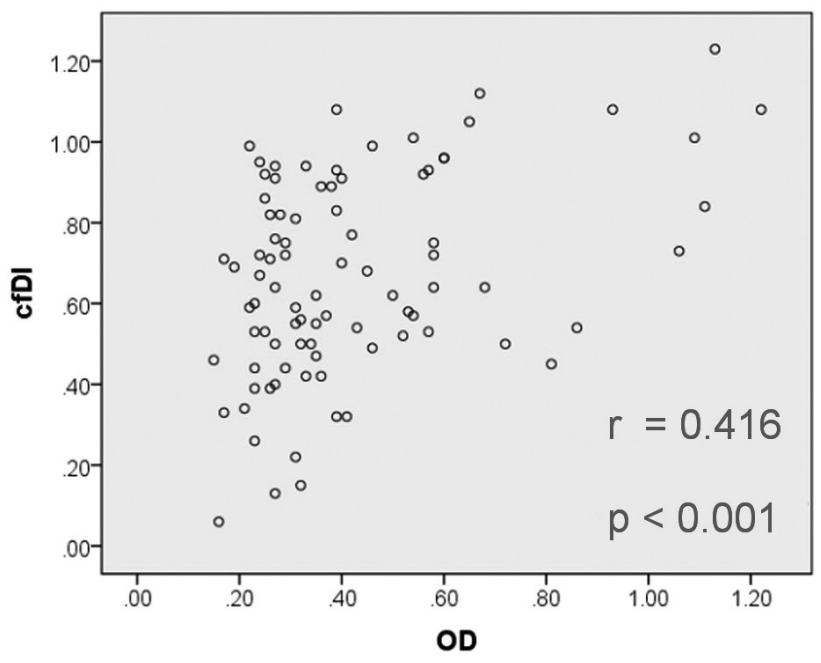

Figure 3. Correlation of DNase I level and cfDI or cfDNA concentration.

An increasing number of reports have shown that cfDNA in patients with cancer is highly variable and mainly comprised short DNA molecules ( $<200 \mathrm{bp})$, which preferentially carry tumor-associated gene aberrations [30]. Our study supports the premise of the shorter feature of cfDNA and lower cfDI of patients with no-MBC as compared to that of patients with BBT. Second, cfDNA differs if isolated from different types of blood samples (serum or plasma) [31]. Plasma samples are preferred over serum samples despite studies showing that cfDNA concentrations tend to be higher in the latter, as the coagulation process affects the spectrum of circulating nucleic acids in serum and thereby contributes to higher variability $[32,33]$. Lastly, the amount of isolated DNA varies greatly between different extraction kits. In the present study, cfDNA was isolated strictly according to the protocol of a commercial kit to reduce the variability as much as possible. Additionally, the properties of the primer pairs and amplicon lengths might have influenced the results. As qPCR-based methods produce indirect estimates of true biological values, inconsistencies in the real-time amplification or differences in the PCR efficiencies of the long and short amplicons can influence cfDI estimation [34].

The DNA clearance rate of patients could directly contribute to the absolute plasma DNA level. Most cfDNA is degraded by DNase I, which is a secreted enzyme whose function has been presumed to control "waste management" in the human system and is eventually cleared from the blood by the liver and kidneys [35]. DNase I activity is mainly influenced by $\mathrm{Ca}^{2+}$ and $\mathrm{Mg}^{2+}$ in the blood. Some have reported significantly decreased DNase I activity in the blood of patients with cancer as compared to healthy controls [23]. However, no study has compared the DNase I activity between patients with no-MBC and patients with BBT. In addition, it has been speculated that cfDI is not significantly influenced by the DNA clearance rate, as both the amounts

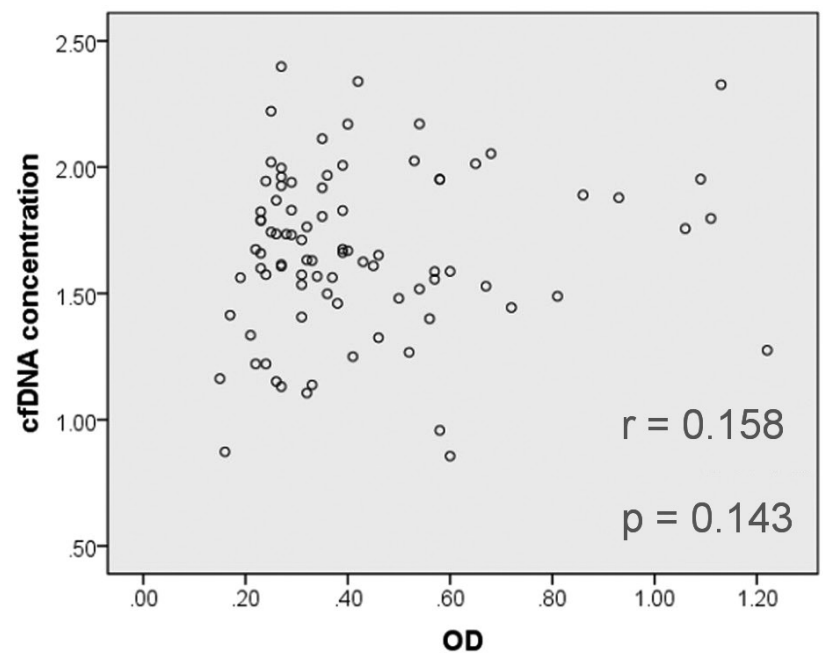

of longer and shorter DNA fragments should be similarly affected [14], but no reports confirm this hypothesis. In the present study, considering all cases were in the early phase of the disease and had no obvious electrolyte disorder, we only tested the DNase I concentration with the sensitive enzyme-linked immunosorbent assay. We found that the average plasma DNase I level of the patients with no-MBC was slightly lower than that of the patients with BBT, but it had no statistical significance. Correlation analysis showed that $\mathrm{cfDI}$ had a remarkable positive correlation with DNase I levels, but cfDNA concentration did not.

In conclusion, our findings show that cfDI plus CTCs is a potential diagnostic biomarker in the differential diagnosis of no-MBC and BBT.

Acknowledgments: This work was supported in part by the National Natural Science Foundation of China [grant numbers 81071753, 81172502, 81202077, 81272916], the Natural Science Foundation of Jiangsu Province [grant number BK20141023], the Program for Development of Innovative Research Team in the First Affiliated Hospital of Nanjing Medical University [grant number IRT-008], and the Priority Academic Program Development of Jiangsu Higher Education Institutions (PAPD).

\section{References}

[1] PANTEL K, ALIX-PANABIERES C. Real-time liquid biopsy in cancer patients: fact or fiction? Cancer Res 2013; 73: 6384-6388. https://doi.org/10.1158/0008-5472.CAN-13$\underline{2030}$

[2] SKIBINSKI A, KUPERWASSER C. The origin of breast tumor heterogeneity. Oncogene 2015; 34: 5309-5316. https://doi. org/10.1038/onc.2014.475

[3] HEITZER E, ULZ P, GEIGL JB. Circulating tumor DNA as a liquid biopsy for cancer. Clin Chem 2015; 61: 112-123. https:// doi.org/10.1373/clinchem.2014.222679 
[4] CROWLEY E, DI NICOLANTONIO F, LOUPAKIS F, BARDELLI A. Liquid biopsy: monitoring cancer-genetics in the blood. Nat Rev Clin Oncol 2013; 10: 472-484. https://doi. org/10.1038/nrclinonc.2013.110

[5] HANASH SM, BAIK CS, KALLIONIEMI O. Emerging molecular biomarkers--blood-based strategies to detect and monitor cancer. Nat Rev Clin Oncol 2011; 8: 142-150. https:// doi.org/10.1038/nrclinonc.2010.220

[6] SCHWARZENBACH H, HOON DS, PANTEL K. Cell-free nucleic acids as biomarkers in cancer patients. Nat Rev Cancer 2011; 11: 426-437. https://doi.org/10.1038/nrc3066

[7] SCHWARZENBACH H. Circulating nucleic acids as biomarkers in breast cancer. Breast Cancer Res 2013; 15: 211. https://doi.org/10.1186/bcr3446

[8] ZONTA E, NIZARD P, TALY V. Assessment of DNA Integrity, Applications for Cancer Research. Adv Clin Chem 2015; 70: 197-246. https://doi.org/10.1016/bs.acc.2015.03.002

[9] HEIDARY M, AUER M, ULZ P, HEITZER E, PETRU E et al. The dynamic range of circulating tumor DNA in metastatic breast cancer. Breast Cancer Res 2014; 16: 421. https://doi. org/10.1186/s13058-014-0421-y

[10] DIEHL F, SCHMIDT K, CHOTI MA, ROMANS K, GOODMAN S et al. Circulating mutant DNA to assess tumor dynamics. Nat Med 2008; 14: 985-990. https://doi.org/10.1038/ $\underline{\text { nm.1789 }}$

[11] BETTEGOWDA C, SAUSEN M, LEARY RJ, KINDE I, WANG Y et al. Detection of circulating tumor DNA in earlyand late-stage human malignancies. Sci Transl Med 2014; 6: 224ra24. https://doi.org/10.1126/scitranslmed.3007094

[12] GARCIA-OLMO DC, GUTIERREZ-GONZALEZ L, RUIZPIQUERAS R, PICAZO MG, GARCIA-OLMO D. Detection of circulating tumor cells and of tumor DNA in plasma during tumor progression in rats. Cancer Lett 2005; 217: 115-123. https://doi.org/10.1016/j.canlet.2004.06.043

[13] WANG BG, HUANG HY, CHEN YC, BRISTOW RE, KASSAUEI $\mathrm{K}$ et al. Increased plasma DNA integrity in cancer patients. Cancer Res 2003; 63: 3966-3968.

[14] UMETANI N, GIULIANO AE, HIRAMATSU SH, AMERSI F, NAKAGAWA T et al. Prediction of breast tumor progression by integrity of free circulating DNA in serum. J Clin Oncol 2006; 24: 4270-4276. https://doi.org/10.1200/ JCO.2006.05.9493

[15] STOTZER OJ, LEHNER J, FERSCHING-GIERLICH D, NAGEL D, HOLDENRIEDER S. Diagnostic relevance of plasma DNA and DNA integrity for breast cancer. Tumour Biol 2014; 35: 1183-1191. https://doi.org/10.1007/s13277-013-1158-4

[16] MOULIERE F, THIERRY AR. The importance of examining the proportion of circulating DNA originating from tumor, microenvironment and normal cells in colorectal cancer patients. Expert Opin Biol Ther 2012; 12 Suppl 1: S209-215. https://doi.org/10.1517/14712598.2012.688023

[17] JIANG P, CHAN CW, CHAN KC, CHENG SH, WONG J et al. Lengthening and shortening of plasma DNA in hepatocellular carcinoma patients. Proc Natl Acad Sci U S A 2015; 112: E1317-1325. https://doi.org/10.1073/pnas.1500076112

[18] MADHAVAN D, WALLWIENER M, BENTS K, ZUCKNICK $\mathrm{M}$, NEES J et al. Plasma DNA integrity as a biomarker for primary and metastatic breast cancer and potential marker for early diagnosis. Breast Cancer Res Treat 2014; 146: 163-174. https://doi.org/10.1007/s10549-014-2946-2

[19] DE MATTOS-ARRUDA L, CORTES J, SANTARPIA L, VIVANCOS A, TABERNERO J et al. Circulating tumour cells and cell-free DNA as tools for managing breast cancer. Nat Rev Clin Oncol 2013; 10: 377-389. https://doi.org/10.1038/ nrclinonc. 2013.80

[20] SHAW JA, BROWN J, COOMBES RC, JACOB J, PAYNE R et al. Circulating tumor cells and plasma DNA analysis in patients with indeterminate early or metastatic breast cancer. Biomark Med 2011; 5: 87-91. https://doi.org/10.2217/ bmm.10.118

[21] DAWSON SJ, TSUI DW, MURTAZA M, BIGGS H, RUEDA $\mathrm{OM}$ et al. Analysis of circulating tumor DNA to monitor metastatic breast cancer. N Engl J Med 2013; 368: 1199-1209. https://doi.org/10.1056/NEJMoa1213261

[22] MAHESWARAN S, SEQUIST LV, NAGRATH S, ULKUS L, BRANNIGAN B et al. Detection of mutations in EGFR in circulating lung-cancer cells. The N Engl J Med 2008; 359: 366-377. https://doi.org/10.1056/NEJMoa0800668

[23] CHEREPANOVA AV, TAMKOVICH SN, BRYZGUNOVA OE, VLASSOV VV, LAKTIONOV PP. Deoxyribonuclease activity and circulating DNA concentration in blood plasma of patients with prostate tumors. Ann N Y Acad Sci 2008; 1137: 218-221. https://doi.org/10.1196/annals.1448.016

[24] TAMKOVICH SN, CHEREPANOVA AV, KOLESNIKOVA EV, RYKOVA EY, PYSHNYI DV et al. Circulating DNA and DNase activity in human blood. Ann N Y Acad Sci 2006; 1075: 191-196. https://doi.org/10.1196/annals.1368.026

[25] CHONG MH, ZHAO Y, WANG J, ZHA XM, LIU XA et al. The dynamic change of circulating tumour cells in patients with operable breast cancer before and after chemotherapy based on a multimarker QPCR platform. Br J Cancer 2012; 106: 1605-1610. https://doi.org/10.1038/bjc.2012.157

[26] VAN DER VAART M, PRETORIUS PJ. The origin of circulating free DNA. Clin Chem 2007; 53: 2215. https://doi. org/10.1373/clinchem.2007.092734

[27] JIN Z, EL-DEIRY WS. Overview of cell death signaling pathways. Cancer Biol Ther 2005; 4: 139-163. https://doi. org/10.4161/cbt.4.2.1508

[28] JAHR S, HENTZE H, ENGLISCH S, HARDT D, FACKELMAYER FO et al. DNA fragments in the blood plasma of cancer patients: quantitations and evidence for their origin from apoptotic and necrotic cells. Cancer Res 2001; 61: 1659-1665.

[29] DELIGEZER U, ERALP Y, AKISIK EE, AKISIK EZ, SAIP P et al. Size distribution of circulating cell-free DNA in sera of breast cancer patients in the course of adjuvant chemotherapy. Clin Chem Lab Med 2008; 46: 311-317. https://doi. org/10.1515/CCLM.2008.080

[30] RYKOVA EY, MOROZKIN ES, PONOMARYOVA AA, LOSEVA EM, ZAPOROZHCHENKO IA et al. Cell-free and cell-bound circulating nucleic acid complexes: mechanisms of generation, concentration and content. Expert Opin Biol Ther 2012; 12 Suppl 1: S141-153. https://doi.org/10.1517/14712598 .2012 .673577 
[31] JUNG M, KLOTZEK S, LEWANDOWSKI M, FLEISCHHACKER M, JUNG K. Changes in concentration of DNA in serum and plasma during storage of blood samples. Clin Chem 2003; 49: 1028-1029. https://doi. org/10.1373/49.6.1028

[32] Wang K, Yuan Y, CHO JH, MCCLARTY S, BAXTER D et al. Comparing the MicroRNA spectrum between serum and plasma. PLoS One 2012; 7: e41561. https://doi.org/10.1371/ journal.pone.0041561

[33] UMETANI N, HIRAMATSU S, HOON DS. Higher amount of free circulating DNA in serum than in plasma is not mainly caused by contaminated extraneous DNA during separation. Ann N Y Acad Sci 2006; 1075: 299-307. https://doi. org/10.1196/annals.1368.040

[34] JUNG K, FLEISCHHACKER M, RABIEN A. Cell-free DNA in the blood as a solid tumor biomarker--a critical appraisal of the literature. Clin Chim Acta 2010; 411: 1611-1624. https:// doi.org/10.1016/j.cca.2010.07.032

[35] HAWES MC, WEN F, ELQUZA E. Extracellular DNA: A Bridge to Cancer. Cancer Res 2015; 75: 4260-4264. https:// doi.org/10.1158/0008-5472.CAN-15-1546 
Supplementary table 1. Primer sequences

\begin{tabular}{ll}
\hline Gene & Sequence (5'-3') \\
\hline CK19 & Forward: TCCGAACCAAGTTTGAGACG \\
hMAM & Forward: ATGAAGTTGCTGATGGTCCTCAT \\
& Reverse: \\
& GTCTTAGACACTTGTGGATTGATTGTCT \\
SBEM & Forward: GTATCCAGCTACTGGTCCTGCT \\
R-actin & Reverse: CAATTGCAGAAGACTCAAGCTG \\
& Forward: GCTGTGCTATCCCTGTACGC \\
& Reverse: TGCCTCAGGGCAGCGGAACC \\
ALU(111bp) & Forward: CTGGCCAACATGGTGAAAC \\
& Reverse: AGCGATTCTCCTGCCTCAG \\
& Forward: ACGCCTGTAATCCCAGCA \\
& Reverse: CGGAGTCTCGCTCTGTCG \\
\hline
\end{tabular}

Abbreviations: $\beta$-actin $=$ beta-cytoplasmic actin 2 ; CK19 = cytokeratin 19 ; hMAM = human mammaglobin; SBEM = small breast epithelial mucin. 
Supplementary Figure 1. Standard curves of ALU (111bp) and ALU (260bp).

\section{ALU (111bp)}

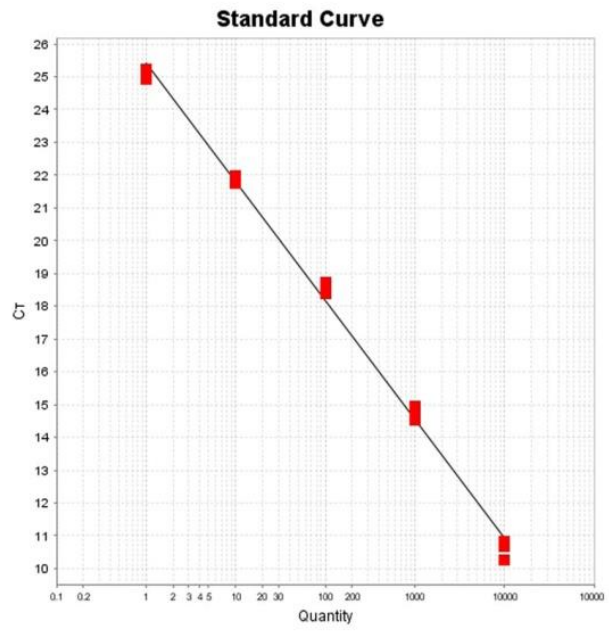

ALU (111bp)

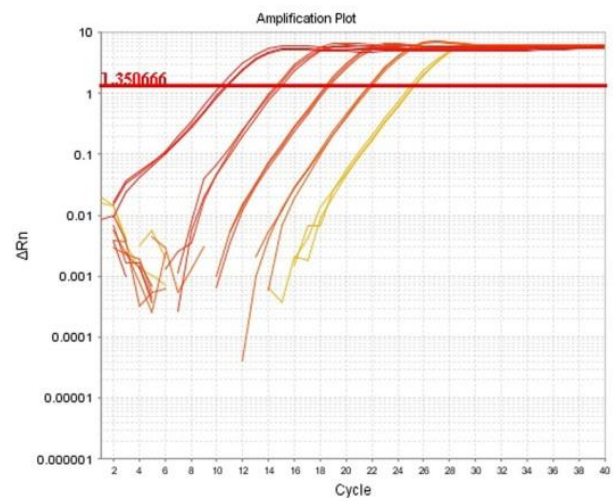

ALU (260bp)

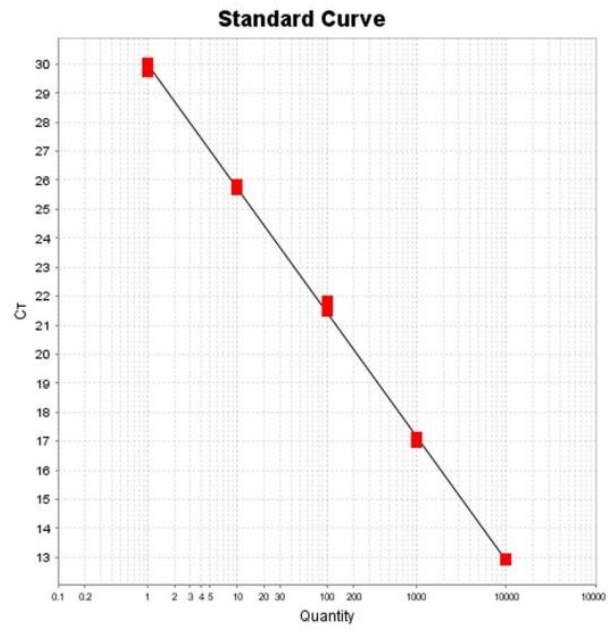

ALU (260bp)

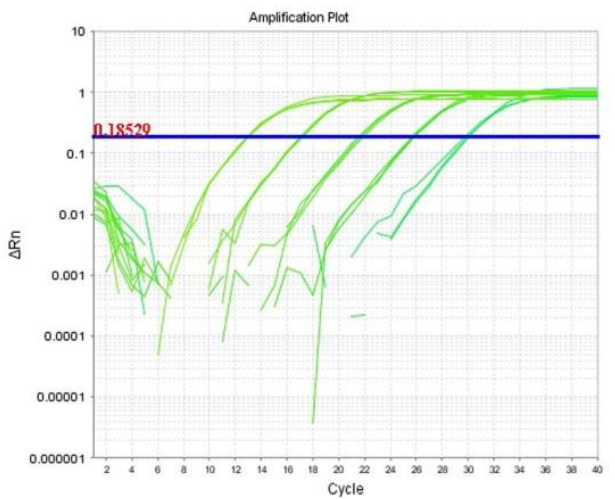

